\title{
Presentación del editor
}

Giaime PALA

Centro de Estudios sobre Movimientos Sociales-UPF

El presente dossier de Rubrica Contemporanea recoge los artículos fruto de las intervenciones presentadas en el seminario "Escriure Història: tàctiques i tècniques", organizado por el Departament d'Història Moderna i Contemporània de la Universitat Autònoma de Barcelona y celebrado en la misma universidad los días 15, 16 y 17 de mayo de 2012. El objetivo que se prefijaron sus organizadores era el de proporcionar a los estudiantes del programa de doctorado "Historia comparada, política y social" una serie de puntos de vista que les ayudaran a tener una idea más clara acerca del largo y laborioso proceso de escritura de la tesis doctoral. Y éste es también el objetivo del dossier, dejando claro desde ahora el elemento que comparten todos sus textos: su carácter más práctico que teórico. En efecto, no se trataba de sustituir a aquel tipo de literatura científica cuyo fin es elaborar propuestas detalladas para redactar una disertación académica, sino de complementarla con reflexiones sobre la escritura académica que nacieran de la formación cultural y la labor profesional de los autores. Reflexiones, en suma, que fueran expresión de lo vivido y experimentado en su práctica historiográfica y que pudiesen estimular el quehacer intelectual del doctorando en Historia.

El penúltimo de los cuatro artículos que componen el dossier es el de Guy Thomson, reconocido hispanista inglés y profesor de Historia en la Universidad de Warwick. En él, el autor repasa su trayectoria de historiador contemporaneísta y presenta su manera de reconstruir hechos históricos generales partiendo del análisis pormenorizado de la vida de personajes emblemáticos. En definitiva, nos explica cómo un biógrafo documentado y atento a establecer un diálogo fecundo con las disciplinas auxiliares de la Historia, puede llegar a articular interpretaciones sobre fenómenos de tipo colectivo.

Por su parte, Anna Caballé dedica su texto a la biografía como género historiográfico y a los problemas metodológicos que plantea al historiador. Desde su experiencia como investigadora de la Unidad de Estudios Biográficos de la Universidad de Barcelona, Caballé nos habla de la peculiar relación que el biógrafo entabla con su biografiado y de las normas básicas para confeccionar un relato biográfico correcto y eficaz.

Los otros dos textos del dossier son de historiadores recién doctorados. Desde luego, una decisión que no es fruto de la casualidad: los organizadores del ya citado seminario consideraron que la similitud y la proximidad en el tiempo entre las experiencias de los asistentes y las de los dos autores podían representar para aquellos una perspectiva útil para su trabajo cotidiano.

El primero es de Àlex Amaya y se propone aportar una serie de consejos comprensibles y aplicables sobre el proceso de redacción de una tesis doctoral de historia como -entre otros- la importancia de una buena planificación temporal, el uso de las fichas y de otros medios digitales de almacenamiento de datos, las maneras de citar las fuentes primarias y secundarias y de iniciar o concluir un capítulo. 


\section{PALA Presentación}

El segundo es del autor de estas líneas, quien formula una reflexión acerca de la narrativa académica que tiene que afrontar el aspirante a doctor en Historia y señala determinados puntos que considera importantes para redactar correctamente una tesis doctoral: el estudio de la gramática, el uso de los diccionarios, el estilo narrativo, el hábito de la lectura como entrenamiento lingüístico cotidiano o la elección de la lengua en la que se escribirá la tesis.

Umberto Eco, autor del célebre manual Cómo se hace una tesis, dijo una vez que la tesis doctoral es el ejercicio intelectual más duro y enervante al que se enfrenta un investigador a lo largo de su vida. Pues bien, en la medida en que los materiales de este dossier ayuden al doctorando a allanar el camino que le llevará a la obtención del grado de doctor en Historia, habrá cumplido con su objetivo. 